Çalışkan, Z., Yüksel, H. / Journal of Yasar University, 2021, 16/63, 1480-1495

\title{
Ürün Yaşam Döngüsü Yönetimi (PLM) Yazılımlarının Seçiminde Kullanılan Kriterlerin ANP Yöntemi İle Sıralanması
}

\section{Sorting The Criteria Used In Selection Of Product Life Cycle Management (PLM) Software By Using ANP Method}

\author{
Zeynep ÇALIŞKAN, Dokuz Eylül Üniversitesi, Türkiye, z_cesur@ hotmail.com \\ Orcid No: 0000-0002-7572-5650 \\ Hilmi YÜKSEL, Dokuz Eylül Üniversitesi, Türkiye, hilmi.yuksel@ deu.edu.tr \\ Orcid No: 0000-0002-9723-3526
}

\begin{abstract}
Öz: Veri üretim hızı düşünüldüğ̈̈nde, Ürün Yaşam Döngüsü Yönetimi’nin (Product Lifecyle Management-PLM), bir yazıllım yardımı olmadan gerçekleştirilmesi oldukça zordur. PLM yazıllımından elde edilecek faydanın en yüksek düzeye taşınması için işletme dinamiklerine ve ürünün doğasına en uygun yazılımın seçilmesi oldukça önemlidir. Bu noktada doğru yazılım seçimi için doğru kriterlerin belirlenmesi ve önem dereceleri göz önüne alınarak değerlendirilmesi gerekmektedir.

Bu çalışmada, Ürün Yaşam Döngüsü Yönetimi (PLM) yazllımı seçiminde kullanılan kriterlerin sıralanması problemi çözümünde Çok Kriterli Karar Verme tekniklerinden olan Analitik Ă̆ Süreci (Analytic Network Process - ANP) yöntemi kullanılmıştır. Literatür taraması ve uzman görüşüne başvurulması neticesinde ortaya çıkan yirmi bir kriterin sıralanması için Super Decision programı kullanılmıştır.
\end{abstract}

Anahtar Sözcükler: PLM, Ürün Yaşam Döngüsü Yönetimi, ANP, Analitik Ăg Süreci

JEL Siniflandirmast: C60, L2, L6, M11

\begin{abstract}
Product Lifecyle Management (PLM) is quite difficult without the help of a software given the increasing speed of data generation in recent conditions. It is very important to choose the software that best suits business dynamics and the nature of the product in order to maximize the benefit to be obtained from PLM software. At this point, it is necessary to determine the right criteria for the right software selection and to be evaluated by considering the importance levels.

In this study, Analytic Network Process (ANP) method, which is one of the Multi Criteria Decision Making techniques, was used to solve the problem of sorting the criteria used in the selection of Product Life Cycle Management (PLM) software. The Super Decision program was used to rank the twenty-one criteria that emerged as a result of literature review and expert opinion.
\end{abstract}

Keywords: PLM, Product Lifecycle Management, ANP, Analytic Network Process

JEL Classification: C60, L2, L6, M11

\section{Giriş}

Üretim yöntemlerinin gelişen teknolojiye ayak uydurması sürecinde Endüstri 4.0. yeni bir basamak oluşturmaktadır. Bu gelişme neticesinde işletmeler için Endüstri 4.0.'1 tüm süreçleri bakımından ele almak, incelemek ve içselleştirmek bir zorunluluk haline gelmiştir. Bütünsel bir yaklaşım ile üretim, ar-ge, kalite, planlama gibi tüm fonksiyonlarda Endüstri 4.0. bakış açısını kullanmak gerekmektedir. Endüstri 4.0, işletmelere verimliliklerini artırmak, esneklik düzeylerini yükseltmek ve maliyetlerini düşürmek için birçok firsat sunarken, işletmeler rekabet güçlerini artırmak için yeni yaklaşımlara ve yöntemlere ihtiyaç duymaktadırlar (Yüksel, 
2020). Endüstri 4.0. devriminin bir parçası olacak teknolojiler üç boyutlu yazıcılar, büyük veri yönetimi, bulut bilişim sistemleri ve veri merkezleri, veri bilimi ve uzmanlığı, yapay zeka ve makine öğrenimi, nesnelerin interneti ve makineler arası iletişim, endüstriyel robotlar ve insan makine ara yüzleri şeklinde özetlenebilir (Özdoğan, 2017:75-100). Tüm bu teknolojiler sayesinde her geçen gün çok daha fazla veri ortaya çıkmakta ve yeni üretilen her veri, ürün ya da hizmetin ortaya çıkış aşamasında önem arz etmekte ve sürece yeni bir yön vermektedir. $\mathrm{Bu}$ noktada ise yeni bir ihtiyaç doğmuştur; Ürün Yaşam Döngüsü Yönetimi.

Ürün yaşamı; ürünün yaşamının başlangıç aşaması yani tasarlanması ve üretilmesi, nihai tüketicide kullanım aşaması ve son olarak da geri dönüşüm ya da bertaraf aşamasından oluşan bir döngüdür (Terzi vd., 2010:364). Ürün yaşam döngüsü yönetimi ise tüm bu evreleri kapsayan bütünsel bir yaklaşımdır (Stark, 2017:13).

Literatüre Ürün Yaşam Döngüsü Yönetimi olarak geçen PLM (Product Lifecycle Management) sistemleri, işletmenin ürünlerini yönetmek için ortaya çıkmış bir sistemdir. PLM, ürünlerde kullanılan en ufak parçadan en geniş ürün yelpazesine kadar tüm ürünleri yönetmek için kullanılan sistemdir (Stark, 2017:13) PLM bir ürüne ait tüm bilgilerin tutulduğu sanal bir ortamdır ve tüm süreç sahipleri ürün ile ilgili ihtiyaç duydukları tüm bilgilere bu ortam üzerinden ulaşabilir, kontrollü bir şekilde değişiklik yapabilir ve yaptığı değişiklikleri diğer süreç sahiplerinin bilgilerine sunabilir. Böylelikle, bir ürünün pazarda ihtiyacının hissedilmesinden ve Ar-Ge Bölümü'nde fikir olarak doğuşundan, müşterideki ömrünü tamamlayana kadarki süreçlerde veriler erişilebilir ve yönetilebilir olmaktadır.

Üretimin ve ürünlerin globalleşmesi, ürüne dair tüm bilgilerin kontrol altında tutulmasını gün geçtikçe zorunlu hale getirmektedir. Ürünlere dair bilgiler bir aşamaya kadar kayıt altına alınsa da ürün yaşamı boyunca tüm verilerin tutulması ve yönetilmesi söz konusu değildi (Stark, 2007:116). Ürünlerin globalleşmesi ile ürünün üretileceği hammadde veya bileşenler farklı ülkelerden gelirken, tasarımı bir ülkede, montajı farklı bir ülkede, satışı ise bir başka ülkede olabilmektedir. Endüstri 4.0. temelli yaklaşımlar ile üretim esnasında simülasyonlar gerçekleştirilmekte, CAD verileri elde edilmekte, makineler arası iletişim ve makine öğrenmeleri ile de yeni veriler üretilmektedir. Müşterilerde kullanımı esnasında bakım verileri tahmin edilmekte ve servis önerileri geliştirilmektedir. Verinin birden çok noktada hızla artışı ise ürün yaşam döngüsünün yönetilmesini zorunlu hale getirmektedir.

Literatür taraması yapıldığında PLM sisteminin hayata geçirilmesi esnasında kullanılan yazılımlara dair seçim kriterlerinin derlendiği, oluşturulduğu, sıralandığı ya da seçildiği bir çalışmaya rastlanmamıştır. Bu çalışmadaki amaç, işletme için ürün yaşam döngüsünün yönetimini sağlayan bir yazılım seçileceğinde ele alınan kriterleri önem derecelerine göre sıralamaktır. Bu sayede seçilen yazılımın işletmeye faydasını en üst düzeye taşımak mümkün 
olacaktır. Çalışmada yöntem olarak yazılım seçim kriterleri arasındaki ilişkinin de çözüm sürecine dahil olması amacıyla Analitik Ağ Süreci (ANP) seçilmiştir. Literatür taraması ve uzman görüşü alınması ile toplam 21 adet kriter belirlenmiş ve bu 21 adet kriter 4 ana kriter gurubu altında incelenmiştir. ANP yönteminin ağ yapısı sayesinde hem kriterlerin birbirleri ile etkileşimleri hem de ana kriter gruplarının etkileşimleri incelenerek bir öncelik sırası belirlenmiştir.

\section{2. Ürün Yaşam Döngüsü Yönetimi (PLM)}

1980'li yılların sonunda teknik tasarımların bilgisayar destekli tasarımlara dönüşmesi ile yeni bir dönem başlamıştır. Bu değişim ile parçaların geometrik yapılarının tasarlanması, daha esnek ve başkalaşmış tasarımların ortaya çıkması mümkün hale gelmiştir. İlerleyen yıllarda ise teknoloji bilgisayar destekli üretimi mümkün hale getirmiştir. Tasarımcıların CAD (Bilgisayar Destekli Tasarım) yazılımları aracılığı ile tasarladıkları parçaların, CAM (Bilgisayar Destekli Üretim) yazılımları ile üretimlerini programlayıp CNC (Bilgisayar Destekli Sayısal Kontrol) tezgahlarında işlettikleri bir dönem başlamıştır. Bu durumun sonucu olarak da daha fazla bilgisayara bağımlı bir dönem başlamıştır. Ortaya çıkan verinin yönetilmesi için öncelikle ürün veri yönetimi anlamına gelen PDM (Product Data Management) doğmuştur. Daha sonra PDM'in yalnızca mühendislik birimlerini kapsaması, ürünün pazarlama, tedarik, müşteri deneyimi gibi alanlarında kullanılamaması sonucu 1990'larda PLM kavramı doğmuştur (Ötleş vd. (PLM), 2015:39; Gürman vd., 2017:337; Mesihovic ve Malmqvist, 2000:3)

Ürün yaşam döngüsü yönetimi; insanları, süreçleri, iş sistemlerini ve ürünün tüm yaşam döngüsünü birleştiren bir iş anlayışını belirtmektedir (Ötleş vd. (PLM), 2015:1). Özden'e göre PLM, endüstriyel teknik bir ürünün fikir aşamasından imha aşamasına kadar uzanan süreci ifade etmektedir (Özden, 2016:35). Gürman ve diğerleri ise PLM'i ürün veri yönetimine odaklanan bir iş ortamı oluşturmak amacıyla kullanılan bir strateji olarak tanımlamıştır (Gürman vd., 2017:336). Ürün yaşam döngüsü yönetimi, tasarımcıda ürün fikrinin doğmasından, ürünün müşterideki ömrünü tamamlayıp bitirmesine kadar geçen süredeki ürün yaşamının her aşamasının takip edilmesi ve yönetilmesi anlamına gelmektedir.

Endüstri 4.0. devrimi ve bilgi teknolojilerinin gelişmesi ile literatürde PLM uygulamalarına dair örnekler artmaktadır. Ötleş ve diğerleri (2015) PLM'in doğuşu, gelişimi, kullanım alanları, faydalarını belirtmişlerdir (Ötleş vd., 2015:36-45). Özden (2016), PLM ve PDM'in yazılımın bir üst noktasında konumlandırılması gerektiği, lazer ile kaynak tekniği üzerinden PLM sayesinde teknolojinin gelişiminin nasıl takip edilmesi gerektiğini önermişlerdir. Bu çalışmada PLM'in havacılık, uzay, inşaat gibi sektörlerde kullanımına ait örneklere yer verilmiştir (Özden, 2016:34-43). Bentaleb ve diğerleri(2016), iç liman sisteminin gelişimine katkı sağlanması 
amacıyla PLM bakış açısı ile bir model önermişler ve büyümesi, ilişkileri, potansiyel eğilimleri incelemişlerdir (Fatimazahra vd., 2016:115-128). Gürman ve diğerleri (2017) tarafından gerçekleştirilen çalışmada, örnek bir işletme için PLM sisteminin süreç yönetimi yeteneklerinin incelenmesi amacıyla teknik olmayan bölümlerde uygulamalar yapılmıştır. Bu uygulamalarda İnsan Kaynakları gibi teknik olmayan bölümlerin de PLM sistemi ile ürün geliştirme gibi teknik süreçler kullanılarak yönetilebileceği sonucuna ulaşılmıştır (Gürman vd., 2017:336-346). Ötleş ve Üçok(2018) çalışmalarında ürün bilgi akışının kapalı olduğu, kapalı döngü ürün yaşam döngüsü yönetimi ile ilgili araştırma konularını değerlendirmişlerdir (Ötleş ve Üçok, 2018:4554) Mesihovic ve Malmqvist (2000), PDM sisteminin özelleştirilmiş ürün çeşitlerinin geliştirilmesi ve yapılandırılması konusundaki faydalarını ele almışlardır (Mesihovic, Malmqvist, 2000:1-4).

PLM ve PDM sistemleri yazılım kavramının bir üstüne konumlanmıştır. Bu sistemlerin ana amacı ürün yaşamı sürecine dahil olan tüm bileşenler arasında bilgi akışı sağlamak ve çift taraflı kazancı sağlamaktır (Özden, 2016:40). PLM ürün ömrü boyunca sürece dahil olan insanları, iş sistemlerini, bilgileri, birimleri birbiri ile entegre hale getirmeyi ve bu sayede de tüm işletme süreçlerinin yeniden yapılandırılmasını amaçlar (Ötleş ve Üçok, 2018:45). Ürün yaşam döngüsü beş aşamadan oluşur. Bunlar; hayal etme, tanımlama, gerçekleştirme, kullanım ve geri dönüşümdür. PLM; ürün bu beş aşamadan geçerken ele alınması gereken dokuz bileşenden oluşur. Bunlar; insan, organizasyon yapısı, metot, imkanlar ve ekipmanlar, uygulamalar, veri, süreç, ürün ve yaşam döngüsüdür. Beş aşamanın tamamının bu dokuz bileşen kapsamında incelenmesi gerekliliği ürün yaşam döngüsünün yönetiminin ne denli zor olduğunu tarif eder (Stark, 2007:112; Terzi vd., 2010:368). Bu sebeple bu alanda yazılım üstü sistemlere ihtiyaç duyulmaktadir.

PLM'in yararları incelenecek olursa; öncelikli olarak daha hızlı pazara sunulmasını, kullanım esnasında daha etkin servis sağlanmasını ve daha iyi yönetilmiş bir kullanım ömrü sağlar. Bunu yanı sıra işletmeler birimleri ve süreçleri arasında artan iletişim ve veriye ulaşma hızı sebebiyle gelişen pazar koşullarına uygun özelleşmiş ürünleri daha kısa sürelerde sağlayabilirler. Tasarlanan ürünün pazara sunum süresi kısalır. Yeni geliştirilen ürünlerin ilk seferde hatasız üretime alınma oranında artış sağlanır. Tüm bu süreçlerin kısalması neticesinde verimlilik artar ve maliyetler düşer. Ürünün devreye alınmasına kadar geçen sürede ortaya çıkan küçük hatalar, PLM sayesinde işbirliği sağlayan ve bilgi akışının parçası olan birimler ile ortadan kalkacaktır (Stark, 2007:120; Ötleş vd., 2015:38; Özden, 2016:38)

PLM ürüne odaklanır. Bu yönüyle tedarik zincirine odaklanan Tedarik Zincir Yönetimi, müşteriye odaklanan Müşteri İlişkileri Yönetimi, kurumsal kaynakların en verimli şekilde kullanılmasına odaklanan Kurumsal Kaynak Yönetimi gibi diğer faaliyetlerden farklılaşır. 
PLM'in güçlü yanı bu noktada ortaya çıkar. Isşletmede bulunan tüm birimler üretilen ürünü bilir. Fakat çoğu zaman tedarik zinciri parçaları, müşteri, insan kaynağı gibi konular tüm çalışanlarca bilinmez. Bu da PLM'i diğer sistemlerden daha güçlü kılar (Stark, 2007:118).

PLM sistemleri öncelikli olarak uzay endüstrisi gibi kapsamlı süreçleri olan işletmelerde başlamış olsa da günümüzde otomotiv, gemi, uçak, inşaat, enerji, savunma sanayi, gıda, tarım, ziraat, giyim, tekstil, taşıma, haberleşme, lojistik gibi sektörlerde uygulama örnekleri görünmektedir.

PLM yazılımlarının olumsuz olarak nitelendirilebilecek yanı ise yazılım bedellerinin yüksekliği, sunucu vb. altyapı ihtiyaçlarının olması ve PLM sisteminin işletmeye kurulumu ve entegrasyonu aşamalarının zorlu olmasıdır (Özden, 2016:39). Bu sebeple bu çalışmanın amacını oluşturan PLM yazılımının doğru seçimini sağlayacak kriterlerin ağırlıkları önem arz etmektedir.

\section{ANP (Analitik Ăg Süreci)}

Analitik Ăg Prosesi (ANP), Thomas L. Saaty tarafından geliştirilmiş, temelleri Analitik Hiyerarşi Prosesi (AHP) üzerine kurulmuş bir çok kriterli karar verme yöntemidir (Saaty, 1996). ANP kriterlerin ilişkilerini ve bu ilişkilerin yönlerini bir ağ şeklinde tanımlayarak ortaya koyan bir karar verme tekniğidir (Ayçin, 2020:31). Daha yüksek seviyeli unsurlar, daha düşük seviyeli unsurlar ile etkileşim halinde olabilir ve kriterlerin önemi alternatiflerin önemini belirlediği gibi, alternatiflerin önemi de kriterlerin önemini etkiler. AHP'de bulunan doğrusal hiyerarşik yapı yerine, karmaşı ilişkilerin ve etkileşimlerin ifade edilebildiği ağ yapısı ile çalışarak, daha doğru bir modelleme ortaya konabilir (Büyükyazıcı ve Sucu, 2003:67).

ANP uygulamaları MS Excel gibi programlarla modellenip çözülebildiği gibi, Expert Choice, SuperDecision gibi alanında uzmanlaşmış yazılımlar kullanılarak da çözüm sağlanabilir (Ayçin, 2020:32). ANP uygulamalarında sırasıyla aşağıdaki işlem adımları takip edilir (Ayçin, 2020:36-38);

Adım 1: Karar problemi tanımlanır. Karar verilecek konu ve bu konuya yönelik seçim kriterleri belirlenir.

Adım 2: Bu adımda ağ yapısı oluşturulur. Belirlenen tüm kriterlerin birbiri ile etkileşiminin olup olmadığı bu adımda belirlenir. Etkileşimin varlığına göre yönü belirlenir. Örneğin aynı küme içerisindeki elemanların birbiri ile etkileşimi varsa İçsel Bağımlılık adını alır. Eğer farklı kümelerin elemanları arasında bir etkileşim var ise Dışsal Bağımlılık, eğer çift yönlü bir dışsal bağımlılık varsa Geribildirim adını alır (Ayçin, 2020:33).

Adım 3: Ağ yapısının belirlenmesinin ardından kriterler arasında ikili karşılaştırma yapılır. İkili karşılaştırma yapılırken ağ yapısı dikkate alınarak birbiri ile ilişkili kümeler ve elemanlar 
arası karşılaştırma yapılır. Bu karşılaştırmada AHP'de olduğu gibi 1-9 Ölçeği kullanılır. Ölçeğe Tablo 1'de yer verilmiştir.

Tablo 1.Temel Ölçüm Değerleri ve Tanımları (Saaty, 2005:257 )

\begin{tabular}{|c|c|c|}
\hline $\begin{array}{l}\text { Önem } \\
\text { Derecesi }\end{array}$ & Tanım & Açıklama \\
\hline 1 & Eşit Önemde & İki Faaliyet de eşit derecede öneme sahiptir. \\
\hline 3 & Biraz Önemli & $\begin{array}{l}\text { Deneyimler ve yargılar bir kriteri diğerine karşı biraz önemli } \\
\text { kılmaktadır. }\end{array}$ \\
\hline 5 & Fazla Önemli & $\begin{array}{l}\text { Deneyimler ve yargılar bir kriteri diğerine karşı güçlü şekilde } \\
\text { önemli kılmaktadır. }\end{array}$ \\
\hline 7 & $\begin{array}{l}\text { Çok Fazla } \\
\text { Önemli }\end{array}$ & Kriter diğerine göre çok güçlü şekilde üstündür. \\
\hline 9 & $\begin{array}{l}\text { Son Derece } \\
\text { Önemli }\end{array}$ & $\begin{array}{l}\text { Eldeki bilgiler ve deneyimler bir kriterin diğerine göre çok büyük } \\
\text { oranda üstün olduğunu belirtmektedir. }\end{array}$ \\
\hline $2,4,6,8$ & Orta Değerler & İki karar arasında uzlaşmada kullanılmaktadır. \\
\hline $\begin{array}{l}\text { Karş1l1klı } \\
\text { Değerler }\end{array}$ & \multicolumn{2}{|c|}{$\begin{array}{l}\text { i, j ile karşılaştırılırken bir değer }(\mathrm{x}) \text { atanmış ise; } \mathrm{j} \text {, i ile karşılaştırılırken atanacak } \\
\text { değerler }(1 / \mathrm{x}) \text { olmaktadır. }\end{array}$} \\
\hline
\end{tabular}

Adım 4: Bu adımda kriterlerin dahil olduğu kümeler için yani ana faktörler için ikili karşılaştırma matrisleri oluşturulur. 3. adımdaki süreç ana kriterler için yürütülür.

Adım 5: Bu adımda başlangıç süper matrisleri oluşturulur. Ağdaki tüm faktörler arasındaki tüm etkileşimlerin ifade edildiği matrisler süpermatris adını alır (Ayçin, 2020:38). Bir ağdaki bileşenlerin faktörlerinin sistemdeki diğer faktörlerin üzerindeki etkisi, ikili karşılaştırma sonucunda elde edilen vektörlerin süpermatrise yerleştirilmesi ile ifade edilir (Ayçin, 2020:38).

Adım 6: Bu adımda ağırlıklandırılmış süpermatris oluşturulur. 4. Adımda elde edilen ağırlıklar ile 5. Adımda oluşan süpermatrisin ilgili kısımları birbiri ile çarpılır ve ağırlıklandırılmış süpermatrsi elde edilir. Ortaya çıkan yeni süpermatrisin sütun toplamları 1'e eşit olur (Ayçin, 2020:38).

Adım 7: Yedinci ve son adımda limit süpermatrisi oluşturulur ve öncelikler belirlenir. $\mathrm{Bu}$ adımda faktörlerin birbiri üzerindeki uzun dönem etkilerini görmek için ağırlıklandırılmış matrisin $(2 k+1)$ sayıda üssü alınır. Burada $k$ çok büyük bir sayı olarak rastgele belirlenir. Amaç tüm sütunları toplamı 1 olan ağırlıklandırılmış süpermatrisin yüksek oranda üssünü alarak tüm satırları aynı değere ulaştırmaktır. Böylece limit matris elde edilir ve matrisin her satırındaki değer o kriterin öncelik değerini gösteren global ağırlık değeri olur (Ayçin, 2020:39). 


\section{Yazılım Seçim Kriterleri}

Bu çalışma kapsamında öncelikle yazılım seçimini esnasında kullanılan kriterler için literatür araştırması gerçekleştirilmiştir. Rostkowska(2014); simülasyon ile modelleme tekniği kullanarak bir çalışma yürütmüş ve çalışmasında seçim için; Deneme Sürümü, Öğrenci Sürümü, Eğitim Dokümanı, Deneme Sürümünde Uygulanan Kısıtlama, Mantıksal Diyagram, Üretim Süreci Simülasyonu, Robotlar Kapalıyken Programlama, Robot Tepkilerini Simüle Etme, 2D Ve 3D Animasyonlu Simülasyon, Obje Parametrelerine Erişim, 3D CAD Dosyası Açabilme, 3D Hazır Model Kullanabilme, Programlama Dili, Standart Kütüphane Genişliği, Üretim İstatistikleri, Rapor Formatı kriterlerini kullanmıştır. Çalışma sonucunda Flexsim, Arena ve Tecnomatix adlı yazılımlar belirtilen kriterler yönünden kıyaslanmış, aynı üretim süreci üç yazılım ile de simüle edilerek hem simülasyon yapma kolaylı̆̆ı hem de raporlamaları kıyaslanarak yorumlanmıştır. 3 yazılım da robotların çevrimdışı programlanmasında zayıf bulunmuştur. Mantık diyagramlarının oluşturulmasında ise Arena ön plana çıkmıştır (Rostkowska, 2014:53-65).

Özen ve Koçak Bulanık AHP ve Bulanık Dematel tekniklerini kullanarak bir çalışma yapmıştır. Çalışmada seçim için; Makine Bakım Modülü, Üretim Modülü, Tedarik Satınalma, Müşteri Bakım Yönetimi, Müşteri İlişkileri, Maliyet Muhasebesi, Finans, Esneklik, Modül Maliyeti, Danışmanlık Maliyeti, Geliştirme Maliyeti, Bakım Maliyeti, Ödeme Şekli, Kurulum Süresi, Firma Referansları, Destek Hizmetlerindeki Yaygınlık, Eğitim Danışmanlık, Satış Sonrası Hizmetler kriterlerini kullanmıştır. Çalışma neticesinde en önemli iki kriter yazılım özellikleri ve maliyet sınıfına giren kriterler olarak tespit edilmiştir ve 1 numaralı alternatif seçilmiştir (Özen ve Koçak, 2017:929-957).

Yeşilyurt ve diğerleri; Kriter ağırlıkları için AHP, Alternatifleri karşılaştırmak için TOPSİS, PROMETHEE yöntemlerini kullanarak bir çalışma gerçekleştirmişlerdir. Çalışmada kriter olarak Yazılım Teknolojileri Ve Kullanım Kolaylığı, Bakım Olanakları, İstatistiksel Bilgi Kayıt, Siber Güvenlik, Maliyet seçilmiştir ve çalışma sonucunda en önemli kriter güvenlik ve firma olarak görülmüş, TOPSİS ve PROMETHEE sonucuna göre de en iyi alternatif VII Pusula firması seçilmiştir (Yeşilyurt vd., 2019:1-21).

Baykasoğlu Çizge Teorisi-Matris Permanent (ÇT-MP) yaklaşımı ile bir çalışma yürütmüştür. Çalışmada kriter olarak Değişik Bakış Açılarını Bütünleştirebilme Ve Bunlar Arasında Geçiş, Fiziksel Sistemle İletişim, Kod Oluşturma, Programlanabilme Özelliği, Modelleme Hacmi, Kapasitesi, Paralel Operasyonları Modelleyebilme, Birbirine Bağlı Olayları Modelleyebilme, Süreçler Arası Etkileşimi Modelleyebilme, Detay Ve Strateji Seviyeleri Modelleyebilme, Rolleri Modelleyebilme, Amaçlara Göre Modelleyebilme, Blokların İsteğe Bağlı Olarak Motife Edilebilmesi, Animasyon Özelliği, İstatistik Dağılımları Kullanabilme, 
Benzetimi Birden Çok Çalıştırabilme, Süreçteki Değişimleri Takip Edebilme, Web Üzerinden Çalışabilme, Daha Çok Platform Ve İşletim Sistemi, Bağımsız Veri Analizi İçin Bilgi-Tabanı Programları İle İletişim, Diğer Yazılımlarla İletişim Kurabilme, Çok Kişili Kullanım İçin A ğ Özelliği, Başka Araçları Entegre Edebilme, Analiz Yapmada Destek, Benzetim Optimizasyonu Özelliği, Alternatifleri Analiz Edebilme, Çıktılardan Anlamlı Sonuçlar Üretebilme, Faktör Analizi, Yukarıdan-Aşağı, Aşağıdan-Yukarı, İçeri-Dışarı Analizi, Maliyet Analizi Yapabilme, Faaliyet Tabanlı Maliyetlendirme, Kolay Kullanılabilme Ve Yardım Unsurları, Kolay Öğrenilebilme Özelliği, Grafiksel Yetenekler, Görsel Yetenekler, Tutarlılık, Eğitim, Satıcı Desteği, Dokümantasyon, Kitap, Web Sitesi Hizmeti kriterleri seçilmiştir. Sonuç olarak Simprocess ve Processmodel isimli iki süreç modelleme yazılımı belirtilen kriterler için çizge teorisi ve matris yöntemi ile kıyaslanmış ve Simprocess yazılımının seçimine karar verilmiştir (Baykasoğlu, 2013:555-566).

Perçin ve Gök Analitik Ağ Süreci (AAS) -TOPSİS yaklaşımları ile bir çalışma yürütmüş, çalışmada Esneklik, Öğrenilebilirlik, İşlevsellik, Kullanıcı Arayüzü, Online Yardım, Satış Sonrası Destek, Güvenilirlik, Teknik Alt Yapı, Finansal Durum, Referanslar, Hizmet Kalitesi, Entegrasyon, Raporlama Ve Analiz, Verimlilik, Veri Güvenliği, Donanım Maliyeti, Sanışmanlık Ve Eğitim Maliyeti, Lisans Maliyeti, Bakım Onarım Maliyeti kriterlerini kullanmıştır. Çalışmada belirlenen kriterler için üç farklı yazılım alternatifi arasında seçim yapılmıştır. Öncelikle kriter ağırlıklarının rasyonel olabilmesi için kriterler arası ağırlıklandırma AAS ile gerçekleşmiş, daha sonra bu ağırlıklara göre alternatif seçimi TOPSİS ile yapılmıştır. Literatürde AAS ve TOPSİS yöntemlerin birlikte kullanıldığı ilk çalışmalardan olmuştur (Perçin ve Gök, 2013:93-114).

Kazancıoğlu ve Burmaoğlu (2013); ERP Yazılım seçimi için TODIM yöntemi kullanmış ve çalışmayı her işletmenin kendi kriterleri için şablon olarak kullanabileceği bir jenerik çalışma olarak ortaya koymuşlardır (Kazancıoglu ve Burmaoglu, 2013:435-452).

Literatürde kullanılan yazılım seçim kriterleri incelendikten sonra PLM yazılımları özelinde kullanılabilecek seçim kriterleri için uzman görüşüne başvurulmuştur. Uzmanlardan alınan görüş neticesinde ortaya çıkan kriterlere Tablo 2'de yer verilmiştir.

Tablo 2. Uzman Görüşü Neticesinde Çıkan Kriterler

\begin{tabular}{|c|l|}
\hline No. & Seçim Kriteri \\
\hline 1. & İhtiyaçları karşılayacak tüm modülleri içerisinde barındırması \\
\hline 2. & Sektör bazında diğer firmaların seçimleri \\
\hline 3. & Üçüncü parti yazılımlar ile entegrasyon süreçlerinin zorluğu \\
\hline 4. & OOTB (Out of The Box) olarak üçüncü parti yazılımlara ne derecede entegre olduğu \\
\hline
\end{tabular}




\begin{tabular}{|c|l|}
\hline 5. & Danışmanlık Maliyetleri \\
\hline 6. & Yazılım Maliyeti \\
\hline 7. & Altyapı için ön şartların maliyeti (sunucu gereklilikleri vb.) \\
\hline 8. & Üçüncü parti yazılımlar ile entegrasyonda lisans maliyeti \\
\hline 9. & Kullanıcı dostu arayüz \\
\hline 10. & $\begin{array}{l}\text { Yazılım teslimi sonrasında gereken revizyonlarının firma içinde anahtar kullanıcılar tarafından } \\
\text { yapılabilirliği }\end{array}$ \\
\hline 11. & Eğitim Yetkinliği \\
\hline 12. & Satış sonrası mühendislik desteği \\
\hline
\end{tabular}

\section{Araştırma Yöntemi}

$\mathrm{Bu}$ çalışmanın amacı işletmelerin ürün yaşam döngüsü yönetimini en etkili şekilde sağlayabilmeleri için en doğru yazılımı seçmelerini sağlamaktır. Günümüz koşullarında sürekli eklenerek çoğalan verinin yönetilmesi fiziki ortamlarda artık çok mümkün değildir. Bu sebeple ürün yaşam döngüsünü etkili bir biçimde yönetmek için sanal sistemlere ihtiyaç artmıştır. $\mathrm{Bu}$ çalışmada, PLM yazılımlarının işletmelerde daha etkin olarak kullanılması için PLM yazılımlarının seçiminde hangi kriterlerin önem kazandığını değerlendirmek ve bu kriterlerin birbirlerine göre önem derecelerini belirlemek amaçlanmıştır.

Çalışmanın kapsamında mevcutta kullanılan PLM yazılımlarına yer verilmiştir. Çalışmanın yapıldığı yıl itibariyle pazarda TeamCenter, Windchill, Fusion LifeCycle, Product Lifecycle Management, Enovia, Upchain PLM, Agile PLM, SAP PLM, Aras PLM, Omnify Empower PLM, Propel PLM gibi yazılımlar yer almaktadır. Kriter seçiminde bahsi geçen yazılımlara hakim uzmanların görüşlerine yer verilmiştir.

Çalışmanın yöntemi olarak ANP seçilmiştir. ANP tekniği ile belirlenen seçim kriterleri kümelere ayrılmış, hem aynı küme içerisindeki kriterlerin birbiri ile ilişkisi, hem de kümeler arası etkileşimler incelenmiştir. Bu sayede karar seviyeleri arasındaki karmaşık ilişkiler de çözüme dahil edilmiş olur. Analitik Hiyerarşi Prosesi (AHP) gibi tekniklerde kullanılan doğrusal hiyerarşi yerine, ağ modeli ile esnek bir şekilde tüm etkileşimlerin gözlemlenmesi amaçlanmıştır.

Literatürde kullanılan seçim kriterleri PLM yazılımı özelinde incelenerek uygun olan kriterler seçilmiş ve uzman görüşü ile elde edilen kriterler ile birlikte Tablo 3'teki şekilde birleştirilmiş ve kriterlerin birbirleri ile ilişkilerinin de incelenebilmesi amaciyla kümelere ayırılmıştır. 
Tablo 3. Ana Kriterler ve Alt Kriterler

\begin{tabular}{|c|c|c|c|}
\hline 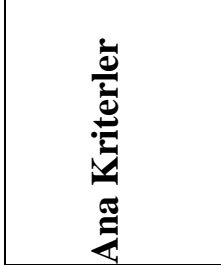 & 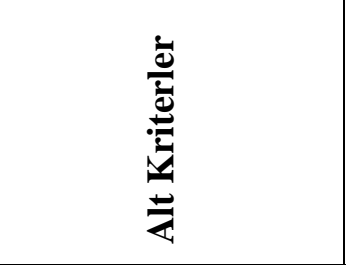 & ב̇ & 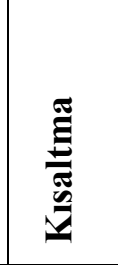 \\
\hline Hizmet & $\begin{array}{l}\text { Deneme Sürümü } \\
\text { Varlığ1 }\end{array}$ & $\begin{array}{l}\text { Yazılımı satın almadan önce deneme yapılabilir olması } \\
\text { yazılıma dair görüş oluşmasını sağladığı için önem arz } \\
\text { eder. }\end{array}$ & H1 \\
\hline Hizmet & $\begin{array}{l}\text { Satış Sonrası } \\
\text { Mühendislik Desteği }\end{array}$ & $\begin{array}{l}\text { Yazılımın satın alınması ve işletmeye entegrasyonu } \\
\text { sonrasında hızlıca teknik destek alınabilecek bir ekibin } \\
\text { varlığı yazılım bilgisinin içselleştirilebilmesi için önem arz } \\
\text { eder. }\end{array}$ & $\mathrm{H} 2$ \\
\hline Maliyet & $\begin{array}{l}\text { Altyapı İçin Ön } \\
\text { Şartların Maliyeti } \\
\text { (sunucu } \\
\text { gereklilikleri vb.) }\end{array}$ & $\begin{array}{l}\text { Yazılım üzerine kurulacağı donanım için bazı } \\
\text { gereksinimlere sahiptir. Bu donanım ihtiyaçlarının niteliği } \\
\text { ne kadar artarsa maliyeti de o kadar artacağı için donanım } \\
\text { gerekliliği seviyesi önem arz etmektedir. }\end{array}$ & M1 \\
\hline Maliyet & $\begin{array}{l}\text { Üçüncü parti } \\
\text { Yazilımlar ile } \\
\text { Entegrasyonda } \\
\text { Lisans } \\
\text { Maliyeti }\end{array}$ & $\begin{array}{l}\text { PLM yazılımları kurumsal kaynak planlaması yazılımları, } \\
\text { kitlesel üretim takibi yazılımları, simülasyon yazılımları } \\
\text { gibi üçüncü parti yazılımlar ile entegre çalışabilmektedir. } \\
\text { Her entegrasyon ayrı bir lisansa tabi olabilir. Bu durum } \\
\text { toplam maliyeti etkilediği için önem arz eder. }\end{array}$ & M2 \\
\hline Maliyet & Yazılım Maliyeti & PLM yazılımının maliyetini ifade eder. & M3 \\
\hline Maliyet & $\begin{array}{l}\text { İlave Modül } \\
\text { Maliyeti }\end{array}$ & $\begin{array}{l}\text { Yazılıma ek olarak alınacak modüllerin maliyetini ifade } \\
\text { eder. }\end{array}$ & M4 \\
\hline Maliyet & $\begin{array}{l}\text { Danışmanlık } \\
\text { Maliyeti }\end{array}$ & $\begin{array}{l}\text { Yazılımın kurulması esnasında firmaya kurulum yapan } \\
\text { danışmanların dokümantasyon vb. ilave istekler için } \\
\text { ödeme aldığı saatlik maliyeti ifade eder. }\end{array}$ & M5 \\
\hline Maliyet & Geliştirme Maliyeti & $\begin{array}{l}\text { İşletmeye özgü mevcutta yazılımda bulunmayan bir } \\
\text { geliştirme yapıldığında ödenen maliyeti ifade eder. }\end{array}$ & M6 \\
\hline Maliyet & Bakım Maliyeti & Yazılım için yıllık olarak ödenen bakım ücretidir. & M7 \\
\hline Maliyet & Lisans Maliyeti & $\begin{array}{l}\text { Yazılım için kullanıcı başına ödenen lisans maliyetini } \\
\text { ifade eder. }\end{array}$ & M8 \\
\hline Maliyet & Ödeme Şekli & Ödemenin vadesini ifade eder. & M9 \\
\hline Mühendislik & $\begin{array}{l}\text { Eğitim Dokümanı } \\
\text { Varlığ1 }\end{array}$ & Eğitim dokümanının mevcutta olup olmadığını ifade eder. & Müh1 \\
\hline
\end{tabular}


Çalışkan, Z., Yüksel, H. / Journal of Yasar University, 2021, 16/63, 1480-1495

\begin{tabular}{|c|c|c|c|}
\hline Mühendislik & Eğitim Yetkinliği & $\begin{array}{l}\text { Yazılımın kurulumu sonrası verilen eğitimin yetkinliğini } \\
\text { ifade eder. Kurulum yapan firmanın eğitici kadrosu önem } \\
\text { arz eder. }\end{array}$ & Müh2 \\
\hline Mühendislik & $\begin{array}{l}\text { Mühendislik } \\
\text { Desteğinin Yurtiçi } \\
\text { Oluşu }\end{array}$ & $\begin{array}{l}\text { Yazılımın kurulumu ve sonrasındaki destek taleplerinin } \\
\text { yurtiçinden sağlanması hem ulaşım hem aynı dilde destek } \\
\text { olacağı için önem arz eder. }\end{array}$ & Müh3 \\
\hline Yazılım & \begin{tabular}{|l|} 
İhtiyaçları \\
Karşılayacak Tüm \\
Modülleri İçerisinde \\
Barındırması
\end{tabular} & $\begin{array}{l}\text { Yazılımın alımında işletmenin ihtiyaç duyduğu tüm } \\
\text { modüllerin paket programın içerisinde olması ilave modül } \\
\text { maliyeti, bakım maliyetinin artması ve ilave danışmanlık } \\
\text { bedelinin oluşmasını önlediği için önem arz eder. }\end{array}$ & Y1 \\
\hline Yazılım & $\begin{array}{l}\text { Sektör Bazında } \\
\text { Diğer Firmaların } \\
\text { Seçimleri }\end{array}$ & $\begin{array}{l}\text { Yazılımın işletmenin rakipleri tarafından seçilmiş olması, } \\
\text { o sektöre hitap ettiğinin bir kanıtı olarak görülebilir. }\end{array}$ & Y2 \\
\hline Yaz1lım & \begin{tabular}{|l|} 
Üçüncü Parti \\
Yazılımlar ile \\
Entegrasyon \\
Süreçlerinin Zorluğu
\end{tabular} & $\begin{array}{l}\text { Yazılımın tasarım programları, kurumsal kaynak } \\
\text { planlaması yazılımları, kitlesel üretim programları ile } \\
\text { entegrasyonu ne kadar zor olursa o kadar maliyet } \\
\text { oluşmasına ve sürecin uzamasına yol açmaktadır. }\end{array}$ & Y3 \\
\hline Yazılım & $\begin{array}{l}\text { OOTB (Out of The } \\
\text { Box) Olarak } \\
\text { Üçüncü Parti } \\
\text { Yazıllımlara Ne } \\
\text { Derecede Entegre } \\
\text { Olduğu }\end{array}$ & $\begin{array}{l}\text { Yazılım satınalındığı esnada üçüncü parti yazılımlar ile } \\
\text { entegrasyonu var ise belirtilen maliyetlere ve süreç } \\
\text { uzamasına katlanılmak zorunda olunmaz. Bu sebeple } \\
\text { mevcutta bu entegrasyonun olması önemlidir. }\end{array}$ & Y4 \\
\hline Yazılım & $\begin{array}{l}\text { Kullanıc1 Dostu } \\
\text { Arayüz }\end{array}$ & $\begin{array}{l}\text { Yazılımın kullanımının kolaylığı işletme içerisinde } \\
\text { süreçlerin kısalmasına ve yazılımın daha kolay } \\
\text { kullanılmasına yol açmaktadır. }\end{array}$ & Y5 \\
\hline Yazılım & \begin{tabular}{|l|} 
Yazılım Teslimi \\
Sonrasında Gereken \\
Revizyonlarının \\
Firma \\
İçinde Anahtar \\
Kullanıcılar \\
Tarafından \\
Yapılabilirliği
\end{tabular} & $\begin{array}{l}\text { Yazılımın kurulumu sonrası revizyonların işletme } \\
\text { içerisinde yapılabiliyor olması maliyet oluşmasını } \\
\text { önlediği için önemlidir. }\end{array}$ & Y6 \\
\hline Yazılım & Siber Güvenlik & $\begin{array}{l}\text { PLM yazılımı işletmenin tüm ürün ve süreç bilgilerini } \\
\text { içerisinde barındırdığı için siber güvenlik seviyesi önem } \\
\text { arz eder. }\end{array}$ & Y7 \\
\hline
\end{tabular}


Yazılım seçiminde kullanılacak kriterler ve bu kriterlerin ait oldukları kümeler belirlendikten sonra kriterler arasında etkileşimin olup olmadığı incelenmiştir. Tablo 4'te kriterler arası etkileşim incelenmiştir. " $\sqrt{ }$ ” sembolü etkileşimin olduğunu, "O" sembolü ise etkileşimin olmadığını ifade etmektedir.

Tablo 4. Kriterler Arası Etkileșim Matrisi

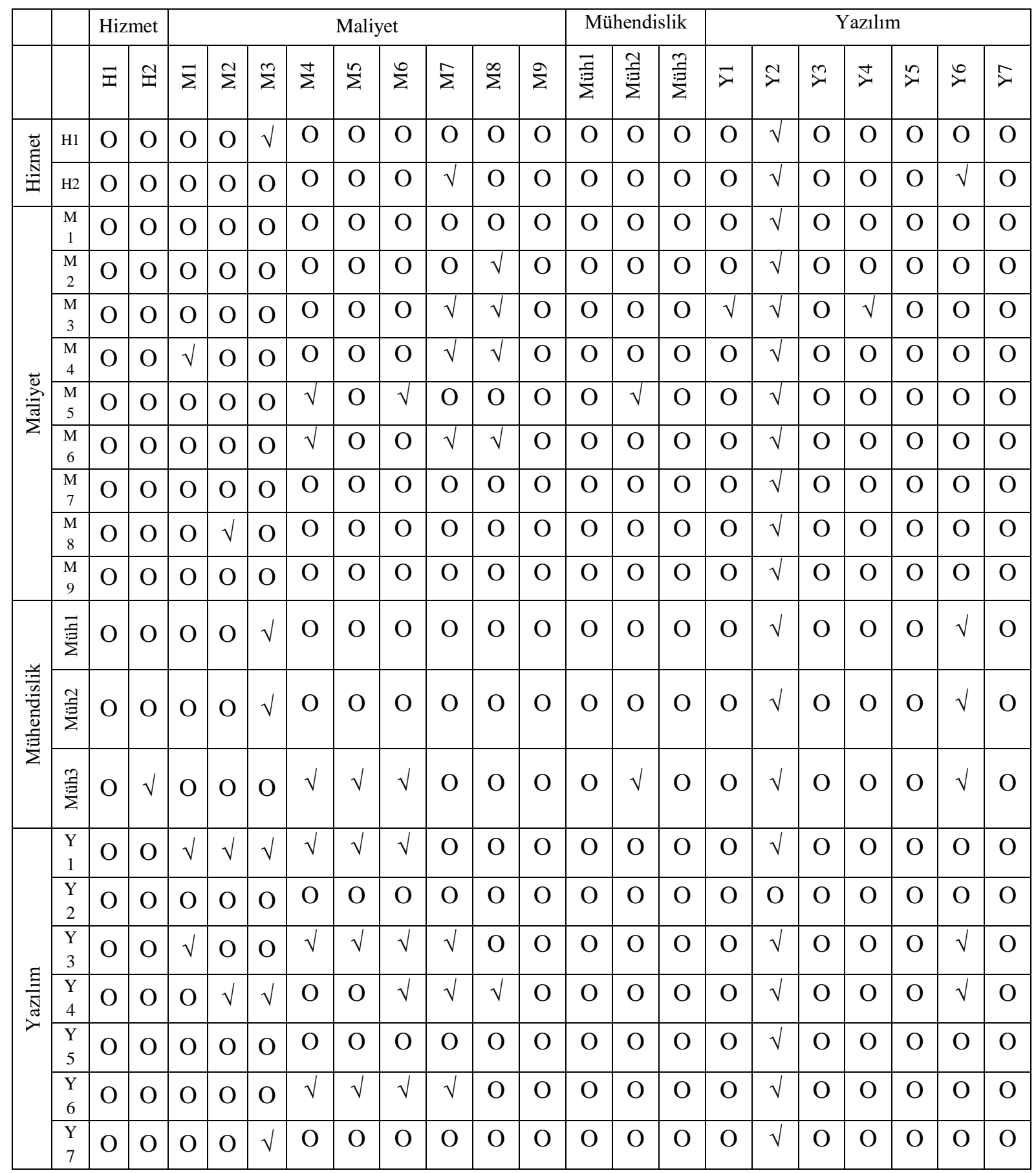


Etkileşim matrisinin oluşturulmasının ardından Super Decision programı yardımıyla kümeler, kriterler, aralarındaki bağlantılar, içsel ve dışsal bağlllıklar, geri bildirimler modellenmiştir. Şekil 1'de modellemeye yer verilmiştir.

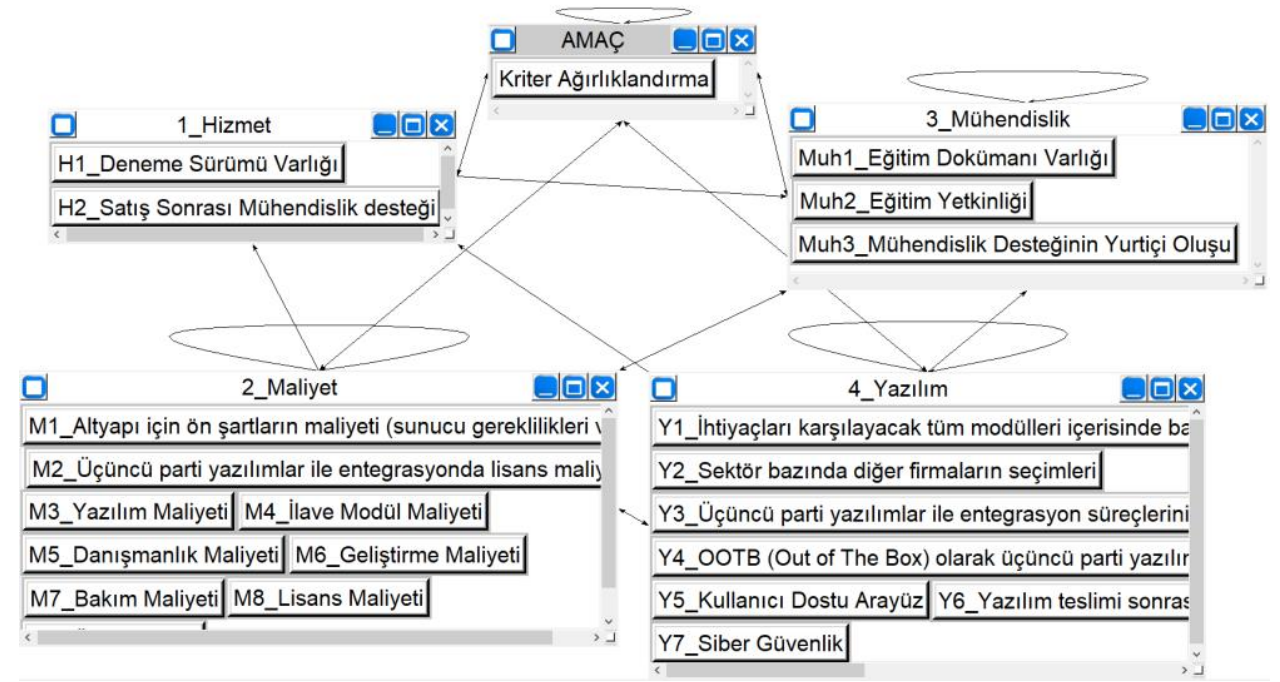

Şekil 1. Ağ Yapısı

Ağ yapısının modellenmesinin ardından kriterler için ikili karşılaştırma matrisleri oluşturulmuştur. İkili karşılaştırma matrisleri oluşturulduktan sonra üç uzmandan Tablo 1'de yer verilen temel ölçüm değerleri kullanılarak değerlendirme yapmaları istenmiş ve uzman görüşlerinin geometrik ortalamaları yazılıma işlenmiştir. Kriterlerin ve kümelerin ikili karşılaştırmalarının tamamlanması sonrası Tablo 5'te yer alan öncelik sırası ve ağırlıklar elde edilmiştir.

Tablo 5. Kriter Ağırlıkları ve Öncelik Sırası

\begin{tabular}{|l|l|l|c|}
\hline No & Kriter & Ăğırlık & $\begin{array}{l}\text { Öncelik } \\
\text { Sırası }\end{array}$ \\
\hline M3 & Yazılım Maliyeti & 0,054 & 1 \\
\hline M8 & Lisans Maliyeti & 0,036 & 2 \\
\hline Y7 & Siber Güvenlik & 0,032 & 3 \\
\hline M7 & Bakım Maliyeti & 0,025 & 4 \\
\hline Y4 & $\begin{array}{l}\text { OOTB (Out Of The Box) Olarak Üçüncü Parti Yazılımlara Ne } \\
\text { Derecede Entegre Olduğu }\end{array}$ & 0,023 & 5 \\
\hline Müh3 & Mühendislik Desteğinin Yurtiçi Oluşu & 0,022 & 6 \\
\hline M1 & Altyap1 İçin Ön Şartların Maliyeti (Sunucu Gereklilikleri Vb.) & 0,019 & 7 \\
\hline Y1 & İhtiyaçları Karş1layacak Tüm Modülleri İçerisinde Barındırmas1 & 0,015 & 8 \\
\hline M4 & İlave Modül Maliyeti & 0,013 & 9 \\
\hline M5 & Danışmanlık Maliyeti & 0,013 & 10 \\
\hline & \multicolumn{2}{|l}{} \\
\hline
\end{tabular}


Çalışkan, Z., Yüksel, H. / Journal of Yasar University, 2021, 16/63, 1480-1495

\begin{tabular}{|l|l|l|c|} 
H2 & Satış Sonrası Mühendislik Desteği & 0,012 & 11 \\
\hline M2 & Üçüncü Parti Yazılımlar İle Entegrasyonda Lisans Maliyeti & 0,011 & 12 \\
\hline Y6 & $\begin{array}{l}\text { Yazılım Teslimi Sonrasında Gereken Revizyonlarının Firma İçinde } \\
\text { Anahtar Kullanıcılar Tarafından Yapılabilirliği }\end{array}$ & 0,011 & 13 \\
\hline M6 & Geliştirme Maliyeti & 0,010 & 14 \\
\hline Müh2 & Eğitim Yetkinliği & 0,008 & 15 \\
\hline Y3 & Üçüncü Parti Yazılımlar İle Entegrasyon Süreçlerinin Zorluğu & 0,007 & 16 \\
\hline H1 & Deneme Sürümü Varlığ1 & 0,005 & 17 \\
\hline Müh1 & Eğitim Dokümanı Varlığı & 0,004 & 18 \\
\hline Y5 & Kullanıcı Dostu Arayüz & 0,003 & 19 \\
\hline M9 & Ödeme Şekli & 0,002 & 20 \\
\hline Y2 & Sektör Bazında Diğer Firmaların Seçimleri & 0,001 & 21 \\
\hline
\end{tabular}

Tablo 6'da göründüğü gibi PLM yazılımı seçiminde en önemli kriter 0,054 ağırlık puanı ile yazılımın maliyetidir. Yazılımın maliyetini 0,036 ağırlık ile lisans maliyeti ve 0,032 ağırlık ile siber güvenlik takip eder. PLM sistemleri işletmenin ürününe dair tüm bilgileri içerisinde barındıran sistemler olduğu için ana maliyet kalemlerini siber güvenlik kriterinin takip etmesi beklenen sonuçları doğrulamıştır. Bunun yanı sıra ödeme şekli ve sektördeki diğer firmaların seçimleri gibi kriterler son sıralarda yer almaktadır.

\section{Sonuç}

Müşteri taleplerinin karmaşıklaştığı ve üretim süreçlerinin günden güne özelleşmek zorunda kaldığı göz önünde bulundurulursa, ürüne dair daha çok veri, daha çok ölçme ve iyileştirme imkanı sunmakla birlikte ürünün yönetilebilir hale gelmesini de sağlamaktadır. Bunun yanı sıra işletmeler artık ürünleri müşterideki kullanım ömrünü tamamlayana kadar sorumluluk sahibidirler. Tüm bu ürün yaşamı üzerinde yönetim kabiliyeti geliştirme gereksinimi ve dijitalleşme süreci PLM ihtiyacını daha gözle görülebilir hale getirmiştir. Bir yazılım olmaksızın ürün yaşam döngüsünün kontrol edilmesi oldukça zordur. Bu da yazılım seçiminde kriter ağırlıkları belirlenmesi ihtiyacını doğurmuştur.

ANP yöntemi hem PLM yazılımı seçimindeki ana kriterlerin seçime etkisini hem de alt kriterlerin birbiri ile etkileşimi ölçtüğü için bu tarz kapsamlı bir yazılımın seçimi için uygun görülmüştür.

Bu çalışmada PLM yazılımı seçiminde kullanılan kriterler ANP yöntemi kullanılarak ağırlıklandırılmıştır. Yöntemin verdiği ağırlık sonuçlarına göre en önemli kriterlerden en önemsiz kriterlere doğru sıralanmıştır. Çıkan sonuçlara göre en önemli kriter yazılımın maliyeti iken önem düzeyi en düşük kriter ise sektör bazında diğer firmaların seçimidir. Yüksek yatırım 
bedelli bu yazılımların seçiminde en önemli kriterin yazılım maliyeti olması günümüz ekonomik şartları göz önünde bulundurulursa beklenen bir durumdur. İşletmeler maliyetlerini düşürerek rekabet avantajı sağlamaya çalışmaktadırlar. Bu doğrultuda sabit maliyeti en az arttıracak seçimi yapma eğitimi ortaya çıkmaktadır. Öte yandan PLM yazılımları işletmenin dinamiklerine göre şekil alan yazılımlardır. Bu bilgi doğrultusunda sektördeki diğer firmaların seçimlerinin en düşük önem düzeyine sahip olması yine makul bir sonuçtur.

Bu çalışmada PLM yazılımı seçiminde kullanılan kriterlerin ağırlıklandırılarak sıralanması sonucu elde edilmiştir. Bu sonuç ile literatüre sağlanan katkı ile PLM yazılımı seçimi gibi gelecek çalışmalara olanak sağlanmıştır. Henüz PLM sistemleri çok fazla yaygınlaşmadığı için uzman kişiler görüşlerini bu kısıtlar altında paylaşmıştır. PLM'in yaygınlaşması gelecek çalışmalarda kısıtların ağırlıklarında farklılıklara yol açabilir. Uygulama PLM yazılımı kullanmakta olan armatür sektöründe hizmet veren bir işletmede konu ile ilgili uzmanlar ile gerçekleştirilmiştir. Sektör bazında bazı kriterlerin ağırlıklarında değişiklikler olması olasıdır. 


\section{KAYNAKÇA}

Ayçin, E. (2020), Çok Kriterli Karar Verme Bilgisayar Uygulamalı Çözümler, Ankara: Nobel Yayıncılık.

Baykasoğlu, A. (2013), İş Süreçleri Modelleme / Benzetim Yazılımı Seçimi İçin Çizge Teorisi ve Matris Yöntemi Temelli Bir Yaklaşım, Gazi Üniversitesi Mühendislik ve Mimarlık Fakültesi Dergisi, 28(3), 555-566.

Büyükyazıcı, M., Sucu M. (2003) The Analytic Hierarcy And Analytic Network Processes, Hacettepe Journal of Mathematics and Statistics, 32, 65-73.

Fatimazahra, B., Fri, M., Mabrouki, C., Semma, A. (2016), Dry Port-Seaport System Development: Application of the Product Life Cycle Theory, Journal of Transportation and Logistics, 1(2), 115-128.

Gurman, E., Ventura, K., Soyuer, H. (2017). Product Lifecycle Management As A Whole Business Management System: An Exploratory Research. Research Journal of Business and Management (RJBM), 4(3), 336-346.

Kazancioğlu, Y., Burmaoğlu, S. (2013). ERP Software Selection with MCDM: Aplication of TODIM Method. Int. J. Business Information Systems, 13(4), 435-452.

Mesihovic, S., Malmqvist, J. (2000) Product Data Management (PDM) System Support for the Engineering Configuration Process, 14th European Conference on Artificial Intelligence ECAI 2000 Configuration Workshop. Ağustos 20-25. Berlin.

Rostkowska, M. (2014) Simulation Of Production Lines In The Education Of Engineers: How To Choose The Right Software?, Management and Production Engineering Review, 5(4), 53-65.

Ötleş, S. Vd. (2015) Ürün Yaşam Döngüsü Yönetimi (PLM), Plastik \& Ambalaj Dergisi, 2015(1), 36-45.

Ötleş, S., Üçok, B. (2018), Kapalı Döngü - Ürün Yaşam Döngüsü Yönetimi, Plastik \& Ambalaj Dergisi, 2018(2), 45-54.

Özden, H. (2016), Endüstriyel Mal ve Hizmet Üretimlerinde PDM, PLM Uygulamaları, Mühendis ve Makina, 57(672), 34-43.

Özdoğan, O. (2017). Endüstri 4.0. Dördüncü Sanayi Devrimi ve Endüstriyel Dönüşümün Anahtarları, İstanbul: Pusula Yayıncılık.

Özen Y., Koçak A. (2017) Bulanık Analitik Hiyerarşi ve Bulanık Dematel Yöntemleri Kullanılarak Kurumsal Kaynak Planlaması Yazılım Seçimi ve Değerlendirilmesi, Manisa Celal Bayar Üniversitesi Yönetim ve Ekonomi Dergisi, (24:3), 929-957.

Perçin, S., Gök, C. (2013), ERP Yazılımı Seçiminde İki Aşamalı AAS-TOPSİS Yaklaşımı, Eskişehir Osmangazi Üniversitesi İ̈BF Dergisi, 8(1), 93-114.

Saaty, Thomas. (1996), Decision making with dependence and feedback: The analytic network process, USA: RWS Publications.

Saaty, Thomas. (2005) Theory and Aplications of Analytic Network Process, USA: RWS Publications.

Stark, J. (2017), Product Lifecycle Management (Volume 3): The Executive Summary, Spinger.

Stark, J.(2007), Global Product: Strategy, Product Lifecycle Management and Billion Customer Question, Spinger.

Terzi, S., Bouras, A., Dutta, D., Garetti, M., Kiritsis, D. (2010) Product lifecycle management - from its history to its new role, Int. J. Product Lifecycle Management, 4(4), 360-389.

Yeşilyurt, B., Karakuş, K., Gür, Ş., Eren T., (2019) Çok Ölçütlü Karar Verme Yöntemleri ile Hastane Bilgi Yönetim Sistemleri İçin Paket Programı Seçimi, Turkish JournalPark Academic, 3(1), 1-21

Yüksel,H., (2020) An Empirical Evaluation of Industry 4.0 Applications of Companies In Turkey: The Case of A Developing Country, Technology in Society, Vol: 63 